\title{
P259: What is the impact of hospital acquired bacteraemia in sub-Saharan Africa?
}

\author{
A Aiken \\ From 2nd International Conference on Prevention and Infection Control (ICPIC 2013) \\ Geneva, Switzerland. 25-28 June 2013
}

\section{Introduction}

The impacts associated with hospital-acquired infections in developing countries are poorly understood, which is largely due to a lack of reliable primary data [1].

\section{Objectives}

Following publication of a major study of paediatric nosocomial bacteraemia in a single hospital in Kenya [2], we aim to make a preliminary estimate of the mortality burden associated with this disease in sub-Saharan Africa.

\section{Methods}

Using data on hospital admissions, per admission risk of disease and associated mortality from Kilifi Hospital, Kenya in 2005 and combining these with contemporaneous regional population estimates, we can make a first estimate of the number of deaths attributable to hospital-acquired bacteraemia in African children.

\section{Results}

Based on this approach, we suggest that approximately 20,000 deaths in children under 5 yrs might have occurred in sub-Saharan Africa in 2005 due to hospital-acquired bacteraemia. However, due to the inherent insensitivity of blood cultures for detecting bacteraemia in children, this might be a substantial underestimate.

\section{Conclusion}

Hospital-acquired bacteraemia in developing countries could have a substantial mortality burden and further work is needed to define the scale and preventability of this problem.

Department of Infectious Diease Epidemiology, London School of Hygiene and Tropical Medicine, London, UK

\section{Competing interests}

None declared.

Published: 20 June 2013

\section{References}

1. Allegranzi B, et al: Burden of endemic health-care-associated infection in developing countries: systematic review and meta-analysis. Lancet 2011, 377(9761):228-41.

2. Aiken $A M$, et al: Risk and causes of paediatric hospital-acquired bacteraemia in Kilifi District Hospital, Kenya: a prospective cohort study. Lancet 2011, 378(9808):2021-7.

doi:10.1186/2047-2994-2-S1-P259

Cite this article as: Aiken: P259: What is the impact of hospital acquired bacteraemia in sub-Saharan Africa? Antimicrobial Resistance and Infection Control 2013 2(Suppl 1):P259.
Submit your next manuscript to BioMed Central and take full advantage of:

- Convenient online submission

- Thorough peer review

- No space constraints or color figure charges

- Immediate publication on acceptance

- Inclusion in PubMed, CAS, Scopus and Google Scholar

- Research which is freely available for redistribution

Submit your manuscript at www.biomedcentral.com/submit
() Biomed Central 